towards eating smaller kid goat meat has developed in many counties but more so in the tropical regions of the Indian subcontinent which includes Pakistan, India, Bangladesh, Nepal, Sri Lanka etc. An average carcass weight of 10-14 kg for the goat is considered normal but the tender meat of goats of dressed carcass weight as low as 3-4 kg has emerged for certain tastes. It is achieved by early slaughtering of teddy breeds of goats in India and Pakistan. Sometimes these small goats look like big cats roaming the slaughterhouse floors in these countries.

Quality traits of any kind of red meat can be divided into three broad lines, composition of the meat to indicate nutritive value, physical characteristics for visual acceptance and processing ease as it relates to the biochemical parameters indicative of normal processing treatments. Goat meat has brick red color and chalk white fat; both colors darken with the age of the animal. The processing characteristics of chevon are known to be as good as of other meats, so it can be easily put in place of beef or beefalo. In some respects like its use in emulsion products, it is as good as lamb and better than beef.

From the nutritional point of view goat meat is a very important source of animal protein in most developing countries, however, not enough research seems to have been carried out on its different nutritional properties and aspects. An average composition of goat meat is as follows, moisture $74-76 \%$, protein $20.6-22.3 \%$, fat $0.5-2.5 \%$ and ash about $1.0 \%$. Chevon contains more essential amino acids like arginine, leucine and iso-leucine than sheep meat. Goat meat has a lesser fat content and appears to have more oleic acid in its fat depots than sheep. Goat meat has higher content of thiamine and riboflavin in the liver but it is low in niacin. Management factors and practices affect goat meat yield and meat quality, like tenderness and juiciness. The paper reviews most of the related aspects of goat meat to conclude some important points.

Table 1 General chemical composition of goat meat from Asia.

\begin{tabular}{|c|c|c|c|}
\hline Components & India/Pakistan & Malaysia & Philippines \\
\hline Moisture \% & 74.2 & 74.0 & 76.0 \\
\hline Proteins (g $100 \mathrm{~g}^{-1}$ ) & 21.4 & 20.6 & 22.3 \\
\hline Fat $\left(\mathrm{g} 100 \mathrm{~g}^{-1}\right)$ & 2.6 & 2.2 & 0.6 \\
\hline Ash $\left(\mathrm{g}_{\left.100 \mathrm{~g}^{-1}\right)}\right.$ & 1.1 & 1.0 & 1.1 \\
\hline Calcium(Ca) $\left(\mathrm{mg} 100 \mathrm{~g}^{-1}\right)$ & 12 & 11 & 6 \\
\hline Phosphorus(P) (mg $\left.100 \mathrm{~g}^{-1}\right)$ & 193 & 154 & 150 \\
\hline Iron (Fe) (mg $\left.100 \mathrm{~g}^{-1}\right)$ & - & 2.1 & 0.4 \\
\hline
\end{tabular}

\title{
Vaginal cytology as a method of estrous determination in the female agouti (Dasyprocta leporina)
}

\author{
Michele Singh ${ }^{1 \dagger}$, Gary W. Garcia ${ }^{1}$, Andrew 0. Adogwa ${ }^{2}$ and Gregory Bourne ${ }^{2}$ \\ ${ }^{1}$ The Open Tropical Forage-Animal Production Laboratory (OTF-APL), Department of Food Production (DFP), Faculty of Science and Agriculture, The University of the \\ West Indies (UWI), St. Augustine, Trinidad and Tobago, West Indies; ${ }^{2}$ School of Veterinary Medicine, Faculty of Medical Sciences, UWI, St. Augustine, Trinidad and \\ Tobago, West Indies
}

\begin{abstract}
Introduction
Intense devastation of tropical ecosystems has been observed in recent times, with irretrievable loss of neo tropical animal genetic resources. This degradation of tropical forests and wildlife has led to the need for innovations with regards to captive rearing of neo tropical animal species, in an attempt to conserve and produce animal protein for local consumption. The agouti (Dasyprocta leprorina) is a neo tropical rodent, found in Central and South America and the Caribbean. Current research suggests that the agouti possess tremendous potential for domestication and semi-commercial production. Knowledge of reproductive physiology forms an integral part of captive breeding strategies. The manipulation of the reproductive cycle of the female agouti is a method of increasing the animal's fecundity. Vaginal cytology is a simple technique used to help characterize stages of the reproductive cycle of females and to evaluate certain diseases of the genital tract. Vaginal cytology is usually used in conjunction with the physical examination, clinical history, vaginoscopy, and hormonal assays to determine the stage of the reproductive cycle. This is especially important if artificial insemination is to be performed. The estrous cycle of the female agouti contains four stages that can be followed cytological. These stages are proestrus, estrus, diestrus, and metestrus and each stage is characterized by the presence, abscence and ratio of typical cell types.
\end{abstract}

${ }^{\dagger}$ E-mail: michele.singh@gmail.com 


\begin{abstract}
Materials and Methods
Vaginal smears of five pluriparous females at least two months post partum were observed over a 90 day period. Approximately $5 \mathrm{~mL}$ of $10 \%$ saline solution was aspirated $4 \mathrm{~cm}$ deep into the cranial vagina and washed 4 times. One milliliter of the final wash was plated on a slide and observed under the microscope (at 4x mag). Leucocytes, nucleated, enucleated and cornified cells were identified in the swabs, in varying ratios, coinciding with the four stages of the estrous cycle.
\end{abstract}

\title{
Results and Conclusion
}

The estrous cycle (mean \pm SD) was found to be 31 ( \pm 4 days) with day $17( \pm 2$ days) being estrus. It was concluded that vaginal cytology is an effective method of characterizing the estrous cycle of the female agouti and confirms the findings of Guimarães (2000).

\section{Reference}

Guimarães DA 2000. Aspectos reprodutivos e endócrinos da puberdade, ciclo estral, gestação e cio pós-parto de cutias (Rodentia:Dasyproctidae), criadas em cativeiro. PhD Thesis, Universidade Federal do Pará. Belém, Pará, Brazil. 94 p.

\section{Dietary electrolyte balance responses in broilers reared in moderately high environmental temperature and high humidity}

\author{
Tanveer Ahmad ${ }^{1 \dagger}$, M. Sarwar ${ }^{2}$, Mahr-Un-Nisa ${ }^{2}$, Ahsan-Ul-Haq ${ }^{3}$, J. Ansari ${ }^{4}$ and Farooq Iqbal ${ }^{1}$ \\ ${ }^{1}$ Department of Livestock Production and Management, Faculty of Veterinary and Animal Sciences, PMAS-Arid Agriculture University, 46300, Rawalpindi, Pakistan; \\ ${ }^{2}$ Institute of Animal Nutrition and Feed Technology; ${ }^{3}$ Department of Poultry Sciences, University of Agriculture, Faisalabad, Pakistan, ${ }^{C}$ Department of Poultry \\ Husbandry, University of Agriculture, Faisalabad, Pakistan; ${ }^{4}$ Poultry Research Institute, Poultry Farms, Bahawalpur, Pakistan
}

\begin{abstract}
Introduction
High environmental temperature coupled with high humidity, a typical feature of monsoon season, has even more harmful effects on the performance of broilers since they feel difficulty in dissipating heat through panting. Several management techniques and dietary modifications have been employed to alleviate heat stress and improve broiler productivity. However, none of these have been considered as a perfect solution in itself. Borges et al. (2003) and Ahmad et al. (2005) employed the concept of electrolyte balance (EB) to counter heat stress in broilers. It was hypothesized that dietary uptake and proper balance of sodium, potassium and chloride can also be helpful to adjust disturbed blood acid-base balance in broilers reared during the hot and humid season. The present study was designed to determine an optimal and practical dietary EB in terms of growth performance and physiological adjustment of broilers reared during the hot and humid season.
\end{abstract}

\section{Material and methods}

A total of 216 broilers were reared up to $42 \mathrm{~d}$ in moderately high temperature and humidity. Chicks were exposed to daily cyclic heat stress

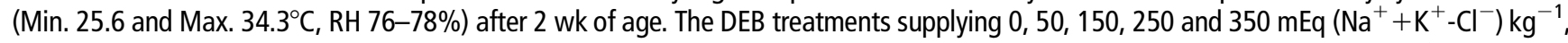
were prepared by adding $\mathrm{NaHCO}_{3}$ and/or $\mathrm{NH}_{4} \mathrm{Cl}$ to the basal diet without altering $\mathrm{K}$ contents $(0.71$ and $0.65 \%$ in starter and finisher diets, respectively). Basal starter $\left(185 \mathrm{mEq} \mathrm{kg}^{-1}\right)$ and finisher $\left(172 \mathrm{mEq} \mathrm{kg}^{-1}\right)$ diets containing $\mathrm{NaCl}$ were served as the control. Each diet was randomly offered to three experimental units having 12 chicks each. The data on live bird performance, water temperature, $\mathrm{pH}$ and consumption, rectal temperature, litter moisture, mortality, carcass characteristics, and blood analysis was collected.

\section{Results}

The DEB 50 and $250 \mathrm{mEq} \mathrm{kg}^{-1}$ significantly $(P<0.05)$ improved the body weight gain, feed intake, feed:gain ratio (Table 1) and water intake. Mortality was not influenced significantly $(P>0.05)$ by DEB treatments. DEB 50 and 250 significantly lowered the blood alkalotic pH and HCO3 concentrations as well as maintained the blood base excess values near to zero on the 43rd day. Significantly $(P<0.01)$ reduced heterophils $(H)$, increased lymphocyte $(L)$ percent, $H / L$ ratios, hemoglobin and hematocrit concentration were also noted by DEB 50 and $250 \mathrm{mEq} \mathrm{kg}^{-1}$. High blood K, Na and Cl were noticed in DEB 250, 350 and $0 \mathrm{mEq} \mathrm{kg}^{-1}$, respectively. However significantly high blood EB was noted in DEB $250 \mathrm{mEq} \mathrm{kg}^{-1}$.

\footnotetext{
${ }^{\dagger}$ E-mail: tanvirah@yahoo.com
} 